\title{
economics-of-security.eu
}

Faisal Rabby and William M. Rodgers III

\section{The Impact of 9/11 and the London Bombings on the Employment and Earnings of U.K. Muslims}

February 2010

Economics of Security Working Paper 24 
Economics of Security Working Paper Series

Correct citation: Rabby, F. and Rodgers, W. M. (2010). "The Impact of 9/11 and the London Bombings on the Employment and Earnings of U.K. Muslims". Economics of Security Working Paper 24, Berlin: Economics of Security.

First published in 2010

(c) Faisal Rabby and William M. Rodgers III 2010

ISSN: 1868-0488

For further information, please contact:

Economics of Security, c/o Department of International Economics, German Institute for Economic Research (DIW Berlin), Mohrenstr. 58, 10117 Berlin, Germany.

Tel: +49 (0)30 $89789-277$

Email: jholmes@diw.de

Website: www.economics-of-security.eu

Economics of Security is an initiative managed by DIW Berlin 


\title{
The Impact of 9/11 and the London Bombings on the Employment and Earnings of U.K. Muslims
}

\author{
Faisal Rabby \\ Missouri State University \\ and \\ William M. Rodgers III \\ Rutgers, the State University of New Jersey, \\ Heldrich Center for Workforce Development and National Poverty Center
}

August 2009

Revised February 2010

JEL Classification: J15, J23, J61, J71

An earlier version of this paper was presented at the meetings of the Southern Economic Association, November 2008. We thank Anne Piehl, John Landon-Lane and Ira Gang for helpful comments and suggestions on an earlier version of this paper. 


\begin{abstract}
Using a difference-in-differences framework, this paper estimates the impact that Britain's July 2005 bombings had on the labor market outcomes of UK residents who are either Muslim by religious affiliation or whose nativity profiles are similar to the terrorists. We find a 10 percentage point decrease in the employment of very young Muslim men relative to nonMuslim immigrants after the London bombings. The drop in employment is accompanied by consistent declines in real earnings and hours worked. A weak association between the 9-11 terrorist attacks and a drop in the employment of very young male immigrants from Muslimmajority countries is also found. The terrorist events had little impact on the employment of older men.
\end{abstract}




\section{Introduction}

The 9-11 terrorists attacks, the March 2004 Madrid bombings, and the July 2005 London bombings (the bombings on $7^{\text {th }}$ July and the attempted bombings on July $21^{\text {st }}$ will be called the "July bombings" hereafter) served as a catalyst for an upsurge in anger and animosity toward Arabs and Muslims living in the United Kingdom. ${ }^{1}$ These events triggered an increase in discrimination that existed prior to 9-11 and the July Bombings.

The source of the pre-existing discrimination has been attributed to the resilient nature of Muslim religious identity, the slow pace of assimilation into the rest of British society, and the weaker soft skills (e.g., language) of Muslims. For example, Shields and Price (2003) find that even after accounting for differences in job-related characteristics, across the various ethnic minority migrant groups, Pakistani and Bangladeshi migrants are less successful in the labor market. This may be due to lower labor demand, especially for Pakistani and Bangladeshi women.

Ameli et al. (2004) find from a pre 9-11 nationwide survey of 1,200 Muslims that Muslim women reported far greater discrimination than Muslim men (IHRC 1999, 2000). After 9/11, the gender difference in reported discrimination narrowed to 2 percentage points (men (78 percent and women 80 percent). The targeting by police and security services of Muslim men appears to explain the narrowing. However, approximately 80 percent of employed Muslims reported incidences of discrimination in the workplace. Similar anti-Muslim responses occurred in the Netherlands and Denmark. ${ }^{2}$

There have been three studies that estimate the impact of the terrorist events' on the labor market outcomes of British Muslims. The evidence suggests no deterioration in the earnings and employment of Muslims can be attributed to the terrorist events. Braakmann (2007a) estimates 
difference-in-differences models using data from the British Labor force survey (LFS) to identify 9-11's impacts, the beginning of the US involvement in Iraq, the Madrid train, and London bombings on the labor market outcomes of 16 to 64 year old UK Arab and Muslim men. Braakman finds that the terrorist attacks had no impact on the real wages, hours worked, and employment probabilities of Arab men. Braakmann (2007b) studies the effects of 9/11 on the reemployment prospects of unemployed Arabs living in Germany, and also finds no change in employment prospects.

Aslund and Rooth (2005) report that after 9/11, Swedish public attitude towards certain minorities changed. However, their analysis of detailed unemployment exit data on the entire Swedish working-age population reveals little evidence of relative changes in the unemployment exit or entry of the eight Muslim-looking minority groups. They conclude that employers behave rationally and do not respond to changes in attitudes toward immigrants as a group.

This paper revisits the following questions. Did UK labor market outcomes become worse for Muslims and immigrants from Muslim-majority countries after 9/11 and after the July bombings? We revisit this question because we suspect that estimates based on the general or working age population mask the adverse impact that Muslim men who fit the age profile of the terrorists faced.

Using the British LFS and a difference-in-differences (DD) methodology, we find that 911 was associated with a relative decrease in the employment of 16 to 25 year old immigrant men from Muslim-majority countries or men who are Muslims by religious affiliation compared to other immigrants. A 10 percentage point decrease in the employment of very young Muslim men relative to non-Muslim immigrants occurred shortly after the London bombings. The drop in employment is accompanied by consistent declines in real earnings and hours worked. A weak 
association between the 9-11 terrorist attacks and a drop in the employment of very young male immigrants from Muslim-majority countries is also found. The terrorist events had little impact on the employment of older men.

\section{Methods}

Our central method is difference-in-differences, where we compare the change in the employment-population ratio, hours worked per week, and real weekly earnings of a target group to that of a comparison group. ${ }^{3}$ Thus, we attempt to remove the impact that labor supply, labor demand and institutional factors have on target group outcomes. ${ }^{4}$

More formally, outcomes for the ith person are described as follows:

$\mathrm{Y}_{\mathrm{irt}}=\beta_{0}+\beta_{1}$ After $_{\mathrm{t}}+\beta_{2}$ Muslim $_{\mathrm{irt}}+\beta_{3}\left(\right.$ After $\left._{\mathrm{t}} * \operatorname{Muslim}_{\mathrm{irt}}\right)+\beta_{4} \mathrm{X}_{\mathrm{irt}}+\beta_{5}\left(\mathrm{X}_{\mathrm{irt}} *\right.$ Muslim $\left._{\mathrm{irt}}\right)$

$+\beta_{6} \mathrm{Z}_{\mathrm{rt}}+\beta_{7}\left(\mathrm{Z}_{\mathrm{rt}} *\right.$ Muslim $\left._{\mathrm{irt}}\right)+\beta_{8}$ Quarter $+\beta_{9}\left(\right.$ Quarter $_{\mathrm{t}} *$ Muslim $\left._{\mathrm{itt}}\right)+\beta_{10}$ Region $_{\mathrm{r}}$ $+\beta_{11}\left(\right.$ Region $_{\mathrm{r}} *$ Muslim $\left._{\mathrm{irt}}\right)+\beta_{12}$ Trend $_{\mathrm{t}}+\mathrm{u}_{\mathrm{irt}}$,

where $Y_{i r t}$ denotes the labor market outcome of person $i$ in region $r$ at time $t$, After $_{t}$ denotes a dummy variable that equals one if the observation comes from any month after a terrorist event (e.g., September 2001 or July 2005), and zero otherwise, and $X_{i r t}$ denotes a vector of individual characteristics that include potential experience, educational attainment, race and ethnicity, marital status, length of stay in the UK, and UK citizenship status. In our earnings equations, $X_{i r t}$ contains occupation and industry variables. $^{5}$

The term $Z_{r t}$ represents quarterly regional unemployment rates, and uarter $_{t}$ contains a series of dummy variables that denote the interview quarter to capture seasonality, and $\operatorname{Trend}_{t}$ is as a cubic function of time (starting from 1 for January 1999) to control for unmeasured, timevarying influences. ${ }^{6}$ The term Region $_{r}$ denotes dummy variables that capture differential effects 
of geographic location. The coefficient $\beta_{3}$ identifies the difference-in-differences effect of a terrorist event on the labor market outcomes of Muslims. ${ }^{7}$

Most of the effects are allowed to differ by Muslim status. This is done to allow for the fact that some factors, such as the business cycle and citizenship status, might have affected the two groups differently over time. There is a possibility that the amount of discrimination varied by location due to differences in the visibility of the target groups. However, other than using the regional dummies and Muslim to non-Muslim population ratios as an index of their visibility, no control is used for geographic variation. ${ }^{8}$

\section{Data and Results}

We use micro data from the British Quarterly Labor Force Survey (LFS) from 1999 to June 2007. In each year, we restrict the sample to men who at the time of the interview were 16 to 54 years of age and were not enrolled in school. ${ }^{9}$ The survey contains information on a person's nativity, which is used to identify whether an individual is from a Muslim-majority country. Also starting in spring 2002, the survey reports individuals' religious affiliations. The latter is probably better than nativity profiles for identifying the potential vulnerable groups. The two target groups are comprised of (a) first-generation male immigrants from Muslim-majority countries (Bangladesh, Egypt, Morocco, Pakistan, Iran, Iraq, Lebanon and Other Middle Eastern countries except Israel) and (b) men living in the UK who reported that they are Muslim by religious affiliation. It is important to note that the latter target group is larger in size, especially when men aged 16-25 are considered. Almost three-quarters (73 percent) of very young men from the Muslim-majority countries were actually Muslims by religion. However, only one-third of Muslim men were immigrants from Muslim-majority countries. This is because most young Muslims are UK-born. 
When constructing target and comparison groups, we consider the fact that 9-11's labor market impact might have varied by age. Given the typical terrorists profile, younger Muslims, Asians, and Arabs are more susceptible to fear and discrimination. ${ }^{10}$ Young Muslim men might have experienced worse outcomes than older Muslim men. To operationalize these ideas, we estimate Equation (1) by age-groups.

As most of the target groups are immigrants or their descendents, our preferred comparison groups are immigrants from non-Muslim majority countries. This is due to the fact that their socio-cultural backgrounds, soft-skills, and language proficiency are a better match than natives. The two comparison groups are immigrants from non-Muslim-majority countries and UK-born men. ${ }^{11}$ After 2002, we use the religion and ethnicity information to construct the following comparison groups: non-Muslim Asian men, non-Muslim white men, non-Muslim British white men, and non-Muslims who are neither Asian nor white.

\section{Summary Statistics}

Table 1 reports summary statistics for our primary group of interest, 16 to 25 year old immigrants from Muslim-majority countries and their corresponding comparison groups. The target group members tend to reside in Greater Manchester, West Yorkshire, Metropolitan West Midlands, Eastern, London, and South East - six of the U.K.'s twelve regions. Eighty percent of the men in our sample live in these 6 regions. Table 1 suggests that from winter 1998 to summer 2006, men in the target group have lower employment-population ratios, work fewer hours, and have lower weekly earnings than other immigrants and UK born men. The average length of stay in the UK of immigrants from Muslim-majority countries is 2.3 years greater than immigrants from other countries. Further, over one-half of Muslim immigrants, in contrast to 39 percent of the other immigrants, are UK citizens. A larger percentage of the target-group men are married. 
Even though marital status, years in the UK, and UK citizenship status should provide "Muslims" with greater economic advantages in the labor market, there are several demographic differences between Muslims and the immigrant comparison groups that offset the advantages associated with marriage, citizenship, and years in the United Kingdom. ${ }^{12}$

Immigrants from Muslim-majority countries have less education and work in lower paying industries and occupations. Among very young men, 26.0 percent of target-group members reported to have no qualification, compared to about 10.4 percent of their comparisongroup counterpart. Young target-group men are concentrated in manufacturing, hotel, restaurant and distribution industries, and sales, process and moving operations, and elementary occupations. Jobs in these industries and occupations tend to pay lower wages and are part-time in nature. Appendix I reports summary statistics that extend the upper age bounds to 29 and 54 . Doing so has no impact on the previous conclusions.

Appendix II reports summary statistics for 16 to 25 year old men, but uses the religious affiliation information to identify whether an individual is Muslim. The labor market outcomes are very similar across Muslim men and immigrant men from Muslim-majority countries. Eighteen percent of young Muslims are married in contrast to 9 percent of the immigrant comparison group. The proportion of Muslims with no qualification (16\%) is higher for Muslims compared to the comparison group. For example, 27 percent of Muslims have 'O' level or lower qualifications compared to 13 percent of immigrants from non-Muslim countries.

Table 2 begins to reveal 9/11's impact on the employment-population ratio, hours worked and weekly earnings of young Muslim men. These basic statistics (non-regression adjusted) indicate that the employment-population ratio is the only labor market indicator of Muslims that the 9/11 and the London Bombings impacted. Also quite striking are the large earnings and 
employment gaps between Muslims and other immigrants.

More specifically, the table shows that from January 1999 to August 2001, 16 to 25-year old Muslim men had employment-population ratios that differed very little from other immigrants: 2.4 percentage points lower. This disadvantage expanded to 12.0 percentage points from October 2001 to December 2002. To isolate 9/11's impact on employment-population ratios, the difference-in-differences estimates are constructed by taking the difference of these two estimates. Doing so generates a precisely estimated 9/11 disadvantage for young Muslim men of 9.5 percentage points. The disadvantage persists over time. In 2004, the DD estimate expands to 9.6 percentage points. Utilizing young UK born men (last column) as the control group also yields a disadvantage to Muslim men. Although large, the DD estimates of 6.3 and 5.9 percentage points have less precision. The difference in outcomes among men between 16 and 54 years of age, which are reported in Appendix I, remains unchanged. ${ }^{13}$

Table 2 also indicates that the July 2005 Bombings had an adverse impact on young Muslim employment-population ratios. Just prior to the bombings, Muslim men had a ratio that was 11.2 percentage points below other immigrants. The disadvantage expanded to 18.0 percentage points. As a result, the DD estimate of the July bombing's impact on Muslim employment is 6.9 percentage points. The table shows no disadvantage associated with the bombing when Muslim men are compared to UK born men. The table presents evidence of a slight decline in the hours worked of young Muslim men associated with 9/11, with no further deterioration several years later. For the July Bombings, a seven-hour Muslim disadvantage is maintained through September 2006. For weekly earnings the most notable result is the substantial wage gap between Muslims and non-Muslims that exist prior to the terrorist attacks. The table provides little if any evidence that both terrorist events led to an expansion in the 
earnings gap between Muslim and other immigrants, and Muslims and UK born men.

\section{Regression Results}

Before presenting the difference-in-differences estimates, we identify the sources of the large employment and earnings gaps between Muslims and other immigrants. To do this, we construct Oaxaca-Blinder decompositions of the employment and earning gaps between Muslims and other immigrants (UK born). The gaps are quite sizeable across age groups, which suggest that even older men might be susceptible to employment and earnings losses due to the terrorist events.

The decompositions in Table 3 indicate that from 1999 to 2006, the employment of immigrants from Muslim countries is 11.3 to 14.8 percentage points lower than other immigrants. Approximately, 10 percentage points or 70 to 95 percent of this difference is unexplained. ${ }^{14}$ For weekly earnings, a 39 to 54 percent gap exists, out of which 30 to 35 percentage points are not explained by differences in education, potential experience, length of stay in the UK, citizenship, marital status, and regional labor market conditions. Panel B compares the employment and earnings of Muslim men to UK Born men. Large Muslim disadvantages persist across age for employment and earnings. Muslim employment is 17.6 to 18.3 percent lower than UK Born men. Only 6.2 to 8.6 percentage points of the gap remains unexplained. The earnings gaps range from 25.2 to 47.5 percent. Here, less of the gap is explained. Education, potential experience, length of stay in the UK, citizenship, marital status, and regional labor market conditions explain 1.5 to 11.3 percentage points of the gaps that range from 25.2 to 47.5 percent.

Table 4 reports regression-adjusted difference-in-differences effects of $9 / 11$ and the July bombings on the employment, hours worked, and earnings of immigrants from Muslim-majority 
countries relative to other foreign-born immigrants (upper panel) and UK-born men (lower panel). For the youngest men (ages 16 to 25 ), some changes in outcomes associated with 9/11 are noticeable. Employment of young men from Muslim-majority countries fell by 9.3 percentage points compared to other immigrants. This relative decrease in employment is sustained through 2004. Weekly hours worked also fall for young Muslim men. The decline persists through 2004. Relative to other immigrants, the weekly earnings of young Muslim men increased after 9/11 by 22.0 and 25.0 percent. A potential explanation for this counter intuitive result is that after $9 / 11$ young Muslim men concentrated in the lower tail of the earnings distribution lost their jobs, pushing the group's post-9/11 mean earnings upward. To check for this possibility, we estimated our models, where we exclude men who have no educational qualifications. No significant difference-in-differences effects on employment and earnings are found when the sample was restricted. ${ }^{15}$ This is consistent with the hypothesis that the event was associated with a decrease in the employment of young "Muslims" who have no qualifications (and therefore are in the lower tail of earnings distribution).

The table shows that when we extend the sample to older workers, the adverse impacts on employment and hours quickly dissipate. We find little if any impact among 16 to 29 year old men, and no impact among 16 to 54 year old men, providing confirmation for our identification strategy.

When the UK-born men are used as the comparison group (Table 4), we find no statistically significant deterioration in the employment and earnings of immigrants from Muslim-majority countries after the July bombings. However, it should be noted that when all of the target-group members are immigrants, estimates using UK-born men as the comparison group are less reliable due to unobservable and unmeasured differences in characteristics such as 
language proficiency and other "soft" skills for which we do not have measures. The second comparison group includes both white Muslims and $2^{\text {nd }}$ generation immigrants from Muslimmajority countries causing a potential downward bias in our estimate. News reports published after 9/11 indicate that white Muslims as well as the $2^{\text {nd }}$ generation Muslim immigrants experienced animosity after the terrorist events. ${ }^{16}$ Besides, there are fewer explanatory variables in the regressions that use the UK-born men as the comparison group. Measures for citizenship and length of stay are excluded to avoid multi-collinearity when all UK-born men are used as the comparison group.

The July bombings did not have any impact on the labor market outcomes of immigrants from Muslim-majority countries. Appendix III shows that there was no statistically significant association between the July bombings and the labor market outcomes of immigrants from Muslim-majority countries compared to other immigrants or UK-natives.

Since spring 2002, the LFS contains information on an individual's religious affiliation. This may be a better proxy for establishing Muslim identity than using country of origin (Muslim-majority country). We use this source of variation to create a new target group to estimate the effect of the July Bombings on Muslim outcomes. Table 5 reports changes in Muslim men's outcomes compared to non-Muslims after the July bombings. The difference-indifferences estimates in the upper panel use non-Muslim immigrants as the comparison group while the lower panel uses UK-born non-Muslim men. The "Basic" model reproduces the estimates in Table 2, the unadjusted means. The "Full" model adds our list of characteristics. Among 16 to 25 year old men, the Muslim employment-population ratio dropped by 10.3 percentage points compared to non-Muslim immigrants in the two years following July 2005. Their relative weekly hours declined by 4.5 to 6.6 hours and weekly earnings fell by up to 32.5 
percent. The relative decline in hours is consistent with the decrease in employment-population ratio.

As we increase the upper bound on age from 25 to 29 and then to 54, the DD estimates for the employment-population ratio and earnings of young Muslim men either dampen or become insignificant. Small reductions in weekly hours worked remain at older ages. We find very little difference in outcomes of Muslim men and all UK-born men, consistent with our view that we are unable to fully capture the hetereogeneity in the sample when native-born men are used for comparison.

\section{Robustness of Results}

Our findings that the employment of very young "Muslim" men deteriorated after both terrorist events can be questioned on several grounds. First, during the post-9/11 years, the relative decline in the employment-population ratio of some groups of young "Muslims" was accompanied by a relative increase in their average earnings. Second, the validity of comparison groups can always be questioned.

We address the first critique by estimating the earnings regression with a restricted sample. To ensure that our identification strategy is capturing the terrorist event's impacts on labor market outcomes, we use pseudo-intervention dates in the DD estimation. To address concern about the comparability of the target and control groups, we explore whether our results are sensitive to the use additional comparison groups.

As mentioned earlier, there was a 22.0 to 25.0 percentage-point relative increase in the weekly earnings of young men from Muslim-majority countries increased after 9/11. However, we find no significant difference-in-differences effects on employment and earnings when we restrict the sample to men without higher education. ${ }^{17}$ This is consistent with the hypothesis that 
9/11 was associated with a decrease in employment of mainly those young "Muslims" who have

low qualifications and therefore are in the lower tail of earnings distribution. ${ }^{18}$

\section{Findings from using Different Intervention Dates}

As an identification check, we incorrectly specify the timing of the 9/11 attacks and bombings. To do this, we estimate the difference-in-differences models with pseudo intervention dates. Using a range of dates from 2003 to 2007, we find that the most statistically significant decrease in young Muslim employment occurred after June 2005, the time of the London bombings. The employment-population ratio of young Muslims in the post-March 2005 and the post-June 2005 data fell by 11 percentage points, with the estimate being significant at 5 percent level.

Table 6 reports the difference-in-differences estimates for young Muslims using June 2004 as the intervention date. The regressions are based on data from January 2003 through June 2005. The upper panel compares Muslims to non-Muslim immigrants and the lower panel compares Muslims to non-Muslim minority men who are neither white nor black. As hypothesized, all of the coefficients are small and none are measured with precision. Table 7 shows difference-in-differences estimates for the employment-ratio using a range of intervention dates between years 1999 and 2004. Several of these intervention dates, including 9-11, are associated with statistically significant decrease in employment of men from Muslim-majority countries. This indicates a lack of robustness of our previous finding on 9-11's effect on the employment of young men from Muslim-majority countries.

Tables 8 and 9 present evidence that supports the robustness of our earlier results for young UK men who are Muslim by religious affiliation. Using a range of dates between 2003 and 2007, we find that the most statistically significant relative decrease in the employment of 
young Muslims occurred after June 2005. Table 8 shows approximately an 11 percentage point drop (significant at 5\% level) in the employment of young Muslims in the post-March 2005 and the post-June 2005 data. Table 9 reports difference-in-differences estimates for three windows of time. Each window contains 24 consecutive months starting from July and ending in June and the $12^{\text {th }}$ month is used as the intervention date for estimating difference-in-differences in the employment of young Muslims. By selecting time-spans and intervention dates in such a way, we potentially keep the seasonal effects similar across the pre- and the post-event months. One would also expect the business cycle movement to be moderate in a 24 -month window. The difference-in-differences effect is statistically significant only for the July 2005 model (column 2, Table 9). A statistically significant 11 percentage-point decrease in Muslim occurred. These results are consistent with our earlier findings that the erosion in the outcomes associated with 9/11 and the July bombings were short-lived.

\section{Summary and Conclusions}

This paper estimates the impacts of the 9-11 terrorist attacks and the London bombings on the employment-population ratio, hours worked, and earnings of UK minority men who fit Muslim stereotypes. Using a natural experiment framework, we find a decrease in the employment-population ratio of 16 to 25 year-old Muslim men after the July bombings relative to their non-Muslim counterparts. There is little persistence over time in the disadvantage's growth. Similar to previous research, we find no decline among older Muslim men.

Our findings are consistent with the hypothesis of an emergence in discrimination against minorities that fit societal stereotypes of young Muslims. Furthermore, the fear of discrimination made it harder for young minority workers to join and remain in the labor market. We have found that after the July bombings young men who are Muslim by religious affiliation 
experienced declines in their employment whereas young men who are immigrants from Muslim-majority countries did not experience this decrease.

Even though we only find that very young Muslims are affected by the terrorist attacks, the result has important implications for the future. Today, the average age of UK's Muslim men is approximately 28 years- 13 years less than the national average. Over one third of UK Pakistanis and Bangladeshis are under 16, the youngest age cohort in the country. Given the very different age profiles of ethnic minorities and UK natives, a significant part of the future growth in the working age population between 1999 and 2009 is forecast to come from these minorities, and it is evident that the youngest age cohort of Muslim workers are far from well-integrated in the UK labor market. ${ }^{19}$

The slower Muslim integration and assimilation into British society might have mutually reinforced the impact that the terrorist events had on their labor market outcomes. Given the faster growth in the population of young UK minority workers, future terrorist activities may affect these groups more widely. To minimize these potential impacts, there must be a greater focus on reducing the persistent employment and earnings gaps that predated the 9/11 and London Bombings. 


\section{References}

Allen, C, and Nielsen S. J. 2002. "Summary Report on Islamophobia in the EU after 11 September 2001." European Monitoring Centre on Racism and Xenophobia. Available at: http://eumc.europa.eu/eumc/material/pub/anti-islam/Synthesis-report_en.pdf

Ameli, Saied, Manzur Elahi and Arzu Merali. 2004. "Social Discrimination: Across the Muslim Divide." Islamic Human Rights Commission, UK. http://www.ihrc.org.uk/file/1903718287_content.pdf

Aslund, Olof, and Dan-Olof Rooth. 2005. "Shifts in attitudes and labor market discrimination: Swedish experiences after 9-11." Journal of Population Economics, 18 (4): 602-629

Bisin, Alberto, Eleonora Patacchini, Thierry Verdier, and Zenou Yves. August 2007. “Are Muslim Immigrants Different in Terms of Cultural Integration?" Journal of the European Economic Association, 6 (2-3), 445 - 456

Braakmann, Nils. December 2007. "Islamistic Terror, the War on Iraq and the Job Prospects of Arab Men in Britain: Does a Country's Direct Involvement matter? University of Lüneburg Working Paper Series in Economics, No. 70.

http://www.leuphana.de/fileadmin/user upload/Forschungseinrichtungen/ifvwl/Working Papers/wp_70_Upload.pdf

Braakmann, Nils. January 2007. "The impact of September 11th, 2001 on the job prospects of foreigners With Arab background - Evidence from German labor market data." University of Lüneburg Working Paper Series in Economics No. 37. http://www.leuphana.de/fileadmin/user_upload/Forschungseinrichtungen/ifvwl/Working Papers/wp_37_Upload.pdf

European Monitoring Centre on Racism and Xenophobia (EUMC). December 2001. "Anti Islamic Reactions in EU after Terrorist Acts against USA." A collection of Country Reports form RAXEN National Focal Points (NFPs) - 12th September to 31st December, 2001. http://eumc.europa.eu/eumc/index.php?fuseaction=content.dsp_cat_content\&catid=3fb3 $\underline{8 a d 3 e 22 b b \& \text { contentid }=3 f b 4 f 8 d 82 d 72 a}$

European Monitoring Centre on Racism and Xenophobia (EUMC). November 2005. "The Impact of 7 July 2005 London Bomb Attacks on Muslim Communities in the EU". Available at: http://eumc.europa.eu/eumc/index.php?fuseaction=content.dsp_cat_content \&catid=43c6 $\underline{8 c 15 f 216 d}$

The Guardian, December 8, 2001, "Britain has a proof record for its treatment of Muslims"

Huber, P. J. 1967. "The behavior of maximum likelihood estimates under non-standard conditions." Proceedings of the Fifth Berkeley Symposium on Mathematical Statistics 
and Probability 1:221-233.

Shields,Michael, A. Price, and Stephen Wheatley. 2003. "The Labour Market Outcomes and Psychological Well-being of Ethnic Minority Migrants in Britain." UK, Home Office Online Report http://www.homeoffice.gov.uk/rds/pdfs2/rdsolr0703.pdf 
Table 1: Summary Statistics for 16 to 25 Year Old Men

\begin{tabular}{|c|c|c|c|c|c|}
\hline Variables & "Muslims" & Other Immigrants & Difference & UK-Born & Difference \\
\hline Employment (\%) & 62.04 & 73.00 & -10.96 & 80.34 & -18.3 \\
\hline Observations & 1,386 & 4,433 & & 57,560 & \\
\hline Hours Worked & 21.86 & 28.92 & -7.06 & 31.16 & -9.31 \\
\hline Observations & 1,254 & 3,989 & & 51,694 & \\
\hline Weekly Earnings (Pounds) & 223.50 & 325.17 & -101.67 & 283.55 & -60.05 \\
\hline Observations & 196 & 755 & & 11,157 & \\
\hline Age & 22.33 & 22.31 & 0.05 & 21.26 & $1.07 *$ \\
\hline UK Citizen (\%) & 51.77 & 39.08 & $12.69^{*}$ & 1.00 & $50.36^{*}$ \\
\hline Married (\%) & 30.86 & 11.33 & $19.85^{*}$ & 4.32 & $26.54^{*}$ \\
\hline Length of stay in UK (Years) & 10.01 & 7.60 & $2.31 *$ & 21.26 & -11.25 \\
\hline \multicolumn{6}{|l|}{ Educational Qualification (\%) } \\
\hline No Qualification & 26.01 & 10.42 & $15.42^{*}$ & 10.88 & $15.13^{*}$ \\
\hline Foreign Education & 23.81 & 36.21 & -12.16 & 2.28 & $21.53^{*}$ \\
\hline O-Level or Below & 23.00 & 16.56 & $6.23 *$ & 41.17 & -18.18 \\
\hline A level or Diploma Equivalent & 13.30 & 19.72 & -6.43 & 30.23 & -16.94 \\
\hline Bachelor's or Higher & 11.54 & 15.24 & -3.58 & 14.16 & -2.63 \\
\hline Missing Value & 2.35 & 1.85 & 0.52 & 1.27 & $1.08^{*}$ \\
\hline \multicolumn{6}{|l|}{ Industry (\%) } \\
\hline Agriculture \& Fishing & 0.00 & 0.91 & -0.91 & 1.48 & -1.48 \\
\hline Energy \& Water & 0.85 & 0.22 & 0.14 & 0.85 & -0.52 \\
\hline Manufacturing & 22.97 & 10.24 & $13.25^{*}$ & 16.81 & $6.16^{*}$ \\
\hline Construction & 1.95 & 9.48 & -8.06 & 13.80 & -11.85 \\
\hline Distribution, Hotels \& Restaurants & 38.25 & 31.19 & $8.07 *$ & 26.79 & $11.46^{*}$ \\
\hline Transport \& Communication & 13.76 & 7.75 & $5.65^{*}$ & 6.98 & $6.78^{*}$ \\
\hline Banking, Finance \& Insurance & 13.22 & 22.12 & -9.19 & 19.03 & -5.81 \\
\hline Public Admin, Education \& Health & 4.77 & 9.83 & -5.20 & 7.92 & -3.15 \\
\hline Other Services & 6.31 & 8.22 & -3.72 & 6.31 & -1.55 \\
\hline Workplace Outside UK & 0.00 & 0.03 & -0.03 & 0.03 & -0.03 \\
\hline \multicolumn{6}{|l|}{ Occupation $(\%)$} \\
\hline Managers and Senior Officials & 7.13 & 8.60 & -2.83 & 7.13 & -1.54 \\
\hline Professional & 6.75 & 8.63 & -3.70 & 6.75 & -1.49 \\
\hline Associate Professional and Technical & 7.46 & 15.07 & -8.10 & 13.01 & -5.55 \\
\hline Administrative and Secretarial & 6.80 & 8.82 & -1.49 & 11.37 & -4.57 \\
\hline Skilled Trades & 8.88 & 12.64 & -4.10 & 22.50 & -13.62 \\
\hline Personal Service & 4.83 & 7.38 & -2.21 & 3.95 & 0.87 \\
\hline Sales and Customer Service & 15.02 & 9.43 & $6.32 *$ & 10.64 & $4.38^{*}$ \\
\hline Process, Plant and Machine Operatives & 15.13 & 7.41 & $7.98^{*}$ & 8.88 & $6.26^{*}$ \\
\hline Elementary/Other & 31.03 & 22.03 & $8.14 *$ & 15.78 & $15.25^{*}$ \\
\hline
\end{tabular}




\section{Table 2: Outcomes for 16 to 25 Year Old Men Pre and Post-9/11 and the July Bombings by Target and Comparison Groups}

\begin{tabular}{|c|c|c|c|c|c|}
\hline Panel A: Employment & Muslims & $\begin{array}{c}\text { Other } \\
\text { Immigrants }\end{array}$ & $\begin{array}{c}\text { Other } \\
\text { Immigrants- } \\
\text { Muslim } \\
\text { Immigrants }\end{array}$ & UK-born & $\begin{array}{c}\text { UK-Born-Muslim } \\
\text { Immigrants }\end{array}$ \\
\hline \multicolumn{6}{|l|}{ 9/11 Effect } \\
\hline Jan.99 to Aug.01 & 71.08 & 73.51 & 2.43 & 82.24 & 11.16 \\
\hline Oct. $01 *$ to*Dec. 02 & 63.92 & 75.87 & 11.95 & 81.34 & 17.42 \\
\hline DD Estimate & & & $-9.52 *$ & & -6.26 \\
\hline Oct.01 to Dec.04 & 62.96 & 75.00 & 12.04 & 80.05 & 17.09 \\
\hline DD Estimate & & & $-9.61 * *$ & & -5.93 \\
\hline \multicolumn{6}{|l|}{ July Bombing Effect } \\
\hline Jan.04 to Jun.05 & 62.63 & 73.78 & 11.15 & 79.78 & 17.15 \\
\hline Aug. 05 to Sept.06 & 60.79 & 78.82 & 18.03 & 77.23 & 16.44 \\
\hline DD Estimate & & & $-6.88+$ & & 0.71 \\
\hline \multicolumn{6}{|l|}{ Panel B: Hours Worked } \\
\hline \multicolumn{6}{|l|}{ 9/11 Effect } \\
\hline Jan.99 to Aug.01 & 23.82 & 28.05 & 4.23 & 31.86 & 8.04 \\
\hline Oct.01 to Dec.02 & 21.18 & 28.39 & 7.21 & 30.82 & 9.64 \\
\hline DD Estimate & & & -2.98 & & -1.60 \\
\hline Oct.01 to Dec.04 & 21.16 & 28.05 & 6.89 & 30.25 & 9.09 \\
\hline DD Estimate & & & -2.66 & & -1.05 \\
\hline Jan.04 to Jun.05 & 22.41 & 29.66 & 7.25 & 31.04 & 8.63 \\
\hline Aug. 05 to Sept.06 & 25.21 & 32.34 & 7.13 & 32.30 & 7.09 \\
\hline DD Estimate & & & 0.12 & & 1.54 \\
\hline \multicolumn{6}{|c|}{ Panel C: Weekly Earnings } \\
\hline Jan.99 to Aug.01 & 185.02 & 322.76 & 137.74 & 269.64 & 131.90 \\
\hline Oct.01 to Dec.02 & 243.07 & 334.42 & 91.35 & 296.44 & 205.09 \\
\hline DD Estimate & & & 46.39 & & -73.19 \\
\hline Oct.01 to Dec.04 & 246.31 & 328.81 & 82.50 & 294.41 & 48.10 \\
\hline DD Estimate & & & 55.24 & & 83.80 \\
\hline Jan.04 to Jun.05 & 266.28 & 302.69 & 36.41 & 302.49 & 36.21 \\
\hline Aug. 05 to Sept.06 & 252.77 & 324.33 & 71.56 & 292.11 & 39.34 \\
\hline DD Estimate & & & -35.15 & & -3.13 \\
\hline
\end{tabular}


Table 3: Oaxaca Decompositions of Employment and Earning Gaps

\begin{tabular}{lcccccc}
\hline \hline Panel A: Relative to Other Immigrants & \multicolumn{2}{c}{ Employment-Population Ratio } & \multicolumn{3}{c}{ Log Weekly Earnings } \\
\hline Effect & $\mathbf{1 6 - 2 5}$ & $\mathbf{1 6 - 2 9}$ & $\mathbf{1 6 - 5 4}$ & $\mathbf{1 6 - 2 5}$ & $\mathbf{1 6 - 2 9}$ & $\mathbf{1 6 - 5 4}$ \\
\hline Total Gap & $0.113^{* *}$ & $0.132^{* *}$ & $0.148^{* *}$ & $-0.391^{* *}$ & $0.520^{* *}$ & $0.539^{* *}$ \\
& $(0.02)$ & $(0.02)$ & $(0.01)$ & $(0.05)$ & $(0.04)$ & $(0.03)$ \\
Explained Gap & 0.005 & $0.026^{* *}$ & $0.040^{* *}$ & $0.094^{* *}$ & $0.160^{* *}$ & $0.213^{* *}$ \\
& $(0.01)$ & $(0.01)$ & $(0.00)$ & $(0.04)$ & $(0.03)$ & $(0.02)$ \\
Residual Gap & $0.109^{* *}$ & $0.106^{* *}$ & $0.108^{* *}$ & $0.297^{* *}$ & $0.360^{* *}$ & $0.325^{* *}$ \\
& $(0.02)$ & $(0.02)$ & $(0.01)$ & $(0.06)$ & $(0.04)$ & $(0.02)$ \\
\hline & 5975 & 12465 & 50566 & 995 & 2239 & 8899 \\
\hline Panel B: Relative to UK Born Men & & & & & $0.377^{* *}$ & $0.475^{* *}$ \\
Total Gap & $0.181^{* *}$ & $0.176^{* *}$ & $0.183^{* *}$ & $0.252^{* *}$ & $0.377^{* *}$ & $(0.02)$ \\
& $(0.02)$ & $(0.01)$ & $(0.01)$ & $(0.05)$ & $(0.03)$ & $0.113^{* *}$ \\
Explained Gap & $0.119^{* *}$ & $0.089^{* *}$ & $0.064 * *$ & 0.015 & $0.057+$ & $(0.02)$ \\
& $(0.02)$ & $(0.01)$ & $(0.01)$ & $(0.05)$ & $(0.03)$ & $0.362^{* *}$ \\
Residual Gap & $0.062^{*}$ & $0.086^{* *}$ & $0.120^{* *}$ & $0.237^{* *}$ & $0.319^{* *}$ & $(0.03)$ \\
\hline & $(0.02)$ & $(0.02)$ & $(0.01)$ & $(0.06)$ & $(0.04)$ & $(0.04)$ \\
\hline
\end{tabular}

Notes: The employment gap models include all men where as the gap in log weekly earnings include only employed men. The samples in the upper panel consist of only $1^{\text {st }}$ generation immigrants from (1) other countries and (2) Muslim-majority countries (Bangladesh Morocco Egypt Pakistan Iran Other-Middle-East Iraq Lebanon). The lower panel shows decompositions of the gaps between the latter group and UK-born men. The time period runs from Winter 1999 to Fall 2006. Coefficients are shown with statistical significances where “**” denotes significance at the 1\% level, “*” denotes significance at the $5 \%$ level, and "+" denotes significance at the $10 \%$ level. Robust standard Errors clustered by repeated observations are shown in parentheses. Explanatory variables are potential experience, potential experience squared, years of education, citizenship, marital status, the regional unemployment rate and ratios of the two groups' population across regions. 
Table 4: Difference-in-differences effects of 9-11 on Labor Market Outcomes of Men from Muslim-Majority Countries

Dec. 1999 through Dec. 2002 with Sept.2001 as Intervention Date

\begin{tabular}{ccccccc}
\hline \hline & \multicolumn{2}{c}{ Ages 16-25 } & \multicolumn{2}{c}{ Ages 16-29 } & \multicolumn{2}{c}{ Ages 16-54 } \\
\hline Relative to Other Immigrants & Basic & Full & Basic & Full & Basic & Full \\
\hline Employed=1 & $-0.095+$ & $-0.092+$ & -0.06 & -0.03 & -0.021 & -0.006 \\
& $(0.057)$ & $(0.054)$ & $(0.042)$ & $(0.039)$ & $(0.022)$ & $(0.020)$ \\
Observations & 2818 & 2818 & 5718 & 5718 & 23306 & 23306 \\
Weekly Hours Worked & -3.272 & -3.647 & -2.583 & -1.053 & -1.558 & -0.478 \\
& $(2.540)$ & $(2.383)$ & $(1.892)$ & $(1.745)$ & $(1.087)$ & $(0.999)$ \\
Observations & 2615 & 2615 & 5314 & 5314 & 21247 & 21247 \\
Log Weekly Earnings & 0.128 & 0.279 & 0.101 & 0.176 & -0.028 & -0.002 \\
& $(0.138)$ & $(0.171)$ & $(0.110)$ & $(0.114)$ & $(0.071)$ & $(0.060)$ \\
Observations & 505 & 505 & 1073 & 1073 & 4222 & 4222 \\
\hline Relative to All UK-Born Men & & & & & & \\
\hline Employed=1 & -0.053 & -0.033 & -0.037 & -0.008 & -0.014 & 0.002 \\
Observations & $(0.050)$ & $(0.049)$ & $(0.038)$ & $(0.036)$ & $(0.020)$ & $(0.019)$ \\
Weekly Hours Worked & 38929 & 38929 & 63446 & 63446 & 238659 & 238659 \\
& -1.495 & -1.45 & -1.154 & -0.093 & -1.077 & -0.037 \\
Observations & $(2.168)$ & $(2.038)$ & $(1.657)$ & $(1.532)$ & $(0.971)$ & $(0.894)$ \\
Log Weekly Earnings & 35791 & 35791 & 58167 & 58167 & 216146 & 216146 \\
& 0.105 & 0.193 & 0.128 & $0.176+$ & 0.01 & 0.03 \\
& $(0.120)$ & $(0.148)$ & $(0.100)$ & $(0.106)$ & $(0.066)$ & $(0.058)$ \\
& 8040 & 8040 & 13917 & 13917 & 53926 & 53926
\end{tabular}

\begin{tabular}{ccccccc}
\hline \hline & \multicolumn{2}{c}{ Ages 16-25 } & \multicolumn{2}{c}{ Ages 16-29 } & \multicolumn{2}{c}{ Ages 16-54 } \\
\hline Relative to Other Immigrants & Basic & Full & Basic & Full & Basic & Full \\
\hline Employed=1 & $-0.096^{*}$ & $-0.09 *^{*}$ & -0.053 & $-0.057+$ & -0.022 & -0.017 \\
& $(0.047)$ & $(0.046)$ & $(0.033)$ & $(0.033)$ & $(0.018)$ & $(0.017)$ \\
Observations & 4203 & 4203 & 8703 & 8703 & 35551 & 35551 \\
Weekly Hours Worked & -3.365 & $-3.577+$ & -2.191 & -2.172 & -1.374 & -0.766 \\
& $(2.083)$ & $(2.020)$ & $(1.552)$ & $(1.512)$ & $(0.898)$ & $(0.853)$ \\
Observations & 3924 & 3924 & 8111 & 8111 & 32449 & 32449 \\
Log Weekly Earnings & $0.231^{*}$ & $0.255+$ & 0.141 & $0.169+$ & 0.018 & 0.028 \\
& $(0.113)$ & $(0.131)$ & $(0.088)$ & $(0.092)$ & $(0.058)$ & $(0.050)$ \\
Observations & 733 & 733 & 1602 & 1602 & 6357 & 6357 \\
\hline Relative to All UK-Born Men & & & & & & \\
\hline Employed=1 & -0.058 & -0.052 & -0.021 & -0.022 & -0.005 & 0 \\
& $(0.041)$ & $(0.040)$ & $(0.030)$ & $(0.030)$ & $(0.016)$ & $(0.016)$ \\
Observations & 57649 & 57649 & 92370 & 92370 & 352820 & 352820 \\
Weekly Hours Worked & -1.322 & -1.69 & -0.181 & -0.341 & -0.408 & 0.078 \\
& $(1.747)$ & $(1.687)$ & $(1.341)$ & $(1.312)$ & $(0.801)$ & $(0.768)$ \\
Observations & 52990 & 52990 & 84712 & 84712 & 319538 & 319538 \\
Log Weekly Earnings & $0.175+$ & $0.212+$ & $0.132+$ & $0.154+$ & 0.016 & 0.018 \\
& $(0.097)$ & $(0.115)$ & $(0.080)$ & $(0.085)$ & $(0.054)$ & $(0.047)$ \\
& 11621 & 11621 & 19817 & 19817 & 78717 & 78717 \\
\hline
\end{tabular}

Notes: Entries are the coefficients of the interaction between the Muslim dummy variable and Post-9/11 dummy variable. All estimates are from OLS regressions. Robust standard errors clustered by groups and years are shown in parentheses. Robust Standard Errors clustered by persons are shown in parentheses. The level of statistical significance are indicated as follows: “*” denotes significance at the $1 \%$ level, “**” denotes significance at the $5 \%$ level, and "+" denotes significance at the $10 \%$ level. 
Table 5: Effects of July Bombings on Labor Market Outcomes of Muslim Men Between ${ }^{\text {st }}$ Quarter of 2004 and 2nd Quarter of 2007

\begin{tabular}{ccccccc}
\hline \hline & \multicolumn{2}{c}{$\mathbf{1 6 - 2 5}$} & & $\mathbf{1 6 - 2 9}$ & \multicolumn{1}{c}{$\mathbf{1 6 - 5 4}$} \\
\hline Relative to Other Immigrants & Basic & Full & Basic & Full & Basic & Full \\
\hline Employed=1 & $-0.137^{* *}$ & $-0.103^{*}$ & -0.042 & -0.024 & $-0.028+$ & -0.026 \\
& $(0.041)$ & $(0.047)$ & $(0.028)$ & $(0.033)$ & $(0.016)$ & $(0.018)$ \\
Observations & 4396 & 4396 & 8477 & 8477 & 29826 & 29826 \\
Weekly Hours Worked & $-6.627^{* *}$ & $-4.469^{*}$ & $-2.712^{*}$ & -1.525 & $-1.866^{*}$ & $-1.724+$ \\
& $(1.757)$ & $(2.031)$ & $(1.301)$ & $(1.523)$ & $(0.772)$ & $(0.892)$ \\
Observations & 4124 & 4124 & 7875 & 7875 & 27341 & 27341 \\
Log Weekly Earnings & $-0.190+$ & $-0.325^{*}$ & 0.06 & -0.023 & 0.059 & 0.032 \\
& $(0.111)$ & $(0.137)$ & $(0.088)$ & $(0.107)$ & $(0.061)$ & $(0.068)$ \\
Observations & 642 & 642 & 1424 & 1424 & 5062 & 5062 \\
\hline Relative to All UK-Born Men & & & & & & \\
\hline Employed=1 & $-0.054+$ & -0.048 & 0.009 & 0.007 & -0.007 & -0.002 \\
& $(0.03)$ & $(0.04)$ & $(0.02)$ & $(0.03)$ & $(0.01)$ & $(0.02)$ \\
Observations & 37016 & 37016 & 57850 & 57850 & 235565 & 235565 \\
Weekly Hours Worked & $-2.424+$ & $-2.787+$ & 0.276 & -0.215 & -0.705 & -0.448 \\
& $(1.32)$ & $(1.51)$ & $(1.06)$ & $(1.23)$ & $(0.67)$ & $(0.77)$ \\
Observations & 33991 & 33991 & 53003 & 53003 & 213003 & 213003 \\
Log Weekly Earnings & -0.045 & $-0.173+$ & $0.122+$ & 0.043 & 0.037 & 0.041 \\
Observations & $(0.09)$ & $(0.11)$ & $(0.07)$ & $(0.09)$ & $(0.06)$ & $(0.06)$ \\
\end{tabular}

Notes: Entries are estimated coefficients of the interaction between Muslim dummy and "post-July 2005" dummy. All results shown were given by OLS regressions. All variables except log weekly earning, hours worked, age, length-of-stay and local unemployment rate are categorical. Log earnings models include only employed men. In the hours worked models, hours are set equal to zero if not employed. Standard errors clustered by "persons" are shown in parentheses. Coefficients are shown with statistical significances where "**” denotes significance at the $1 \%$ level, “*” denotes significance at the $5 \%$ level, and "*” denotes significance at the $10 \%$ level. 
Table 6: Difference-in-Differences in Labor Market Outcomes of Muslims when June 2004 is Used as an Intervention Date

\begin{tabular}{|c|c|c|c|c|c|c|}
\hline \multirow[b]{2}{*}{ Relative to Other Immigrants } & \multicolumn{2}{|c|}{$16-25$} & \multicolumn{2}{|c|}{ 16-29 } & \multicolumn{2}{|c|}{ 16-54 } \\
\hline & Basic & Full & Basic & Full & Basic & Full \\
\hline \multirow[t]{2}{*}{ Employed=1 } & 0.026 & 0.016 & 0.005 & -0.015 & 0.002 & -0.011 \\
\hline & $(0.046)$ & $(0.046)$ & $(0.033)$ & $(0.033)$ & $(0.018)$ & $(0.017)$ \\
\hline Observations & 2655 & 2655 & 5157 & 5157 & 18897 & 18897 \\
\hline \multirow[t]{2}{*}{ Weekly Hours Worded } & 0.092 & -0.439 & -0.476 & -1.297 & 0.063 & -0.605 \\
\hline & $(2.090)$ & $(2.077)$ & $(1.563)$ & $(1.536)$ & $(0.915)$ & $(0.867)$ \\
\hline Observations & 2494 & 2494 & 4807 & 4807 & 17343 & 17343 \\
\hline \multirow[t]{2}{*}{ Log Weekly Earnings } & 0.043 & -0.006 & 0.105 & 0.051 & 0.087 & 0.034 \\
\hline & $(0.126)$ & $(0.136)$ & $(0.100)$ & $(0.096)$ & $(0.066)$ & $(0.063)$ \\
\hline Observations & 394 & 394 & 852 & 852 & 3222 & 3222 \\
\hline \multicolumn{7}{|c|}{ Relative to All Minorities (Except Black) } \\
\hline \multirow[t]{2}{*}{ Employed $=1$} & 0.021 & 0.025 & 0.007 & 0.02 & 0 & 0.007 \\
\hline & $(0.046)$ & $(0.046)$ & $(0.035)$ & $(0.035)$ & $(0.019)$ & $(0.018)$ \\
\hline Observations & 3055 & 3055 & 5027 & 5027 & 16092 & 16092 \\
\hline \multirow[t]{2}{*}{ Weekly Hours Worked } & 0.306 & 0.827 & -0.386 & 0.536 & -0.112 & 0.28 \\
\hline & $(1.950)$ & $(1.921)$ & $(1.603)$ & $(1.560)$ & $(0.956)$ & $(0.898)$ \\
\hline Observations & 2837 & 2837 & 4644 & 4644 & 14817 & 14817 \\
\hline \multirow[t]{2}{*}{ Log Weekly Earnings } & -0.102 & -0.111 & -0.054 & -0.05 & -0.009 & -0.01 \\
\hline & $(0.127)$ & $(0.137)$ & $(0.105)$ & $(0.105)$ & $(0.068)$ & $(0.064)$ \\
\hline Observations & 392 & 392 & 709 & 709 & 2548 & 2548 \\
\hline \multicolumn{7}{|c|}{$\begin{array}{l}\text { Notes: All regressions use data from January } 2003 \text { through June } 2005 \text {. Entries are estimated coefficients of } \\
\text { the interaction between Muslim dummy and "post-July } 2004 \text { " dummy. All results shown were estimated } \\
\text { with OLS. All variables except log weekly earning, hours worked, age, length-of-stay and local } \\
\text { unemployment rate are categorical. Log earnings models include only employed men. In the hours worked } \\
\text { models, hours are set equal to zero if not employed. Standard errors clustered by "persons" are shown in } \\
\text { parentheses. Coefficients are shown with statistical significances where "**" denotes significance at the } \\
1 \% \text { level, "**" denotes significance at the 5\% level, and "+" denotes significance at the } 10 \% \text { level. }\end{array}$} \\
\hline
\end{tabular}


Table 7: Difference-in-differences Effects on Employment of Young Men from Muslim-majority Countries

\begin{tabular}{cc}
\hline Dates & D-D Estimate \\
\hline Sept.1999 & $-0.146^{*}$ \\
Dec.1999 & $-0.161^{* *}$ \\
Mar.2000 & $-0.183^{* *}$ \\
Jun.2000 & $-0.190^{* *}$ \\
Sept.2000 & $-0.153^{* *}$ \\
Dec.2000 & $-0.126^{*}$ \\
Mar.2001 & $-0.102^{*}$ \\
Jun.2001 & $-0.088+$ \\
Sept.2001 & $-\mathbf{0 . 0 8 6 +}$ \\
Dec.2001 & $-0.102^{*}$ \\
Mar.2002 & $-0.083+$ \\
Jun.2002 & -0.060 \\
Sept.2002 & -0.068 \\
Dec.2002 & -0.053 \\
Mar.2003 & -0.060 \\
\hline "+” denotes significance at the 10\% level. & \\
\hline
\end{tabular}

Table 8: DD Effects on Employment of Young Muslim Men

\begin{tabular}{cc}
\hline \hline Date & D-D Estimate \\
\hline Jun-04 & $-\mathbf{0 . 0 4 9}$ \\
Sep-04 & $-0.089+$ \\
Dec-04 & $-0.090+$ \\
Mar-05 & $-0.119^{*}$ \\
Jun-05 & $-0.111^{*}$ \\
Sep-05 & $-0.098^{*}$ \\
Dec-05 & $-0.074+$ \\
Mar-06 & -0.009 \\
Jun-06 & -0.010 \\
\hline Notes: Each regression uses 4233 observations between Spring 2003 and Autumn \\
2007. All estimates are from OLS regressions. Robust Standard Errors clustered \\
by groups and years are shown in parentheses. Robust Standard Errors clustered \\
by persons are shown in parentheses. Coefficients are shown with statistical \\
significances where “**" denotes significance at the 1\% level, “*” denotes \\
significance at the 5\% level, and “+” denotes significance at the 10\% level. \\
\hline
\end{tabular}


Table 9: Difference-in-Differences in Employment of Young Muslim Men Between Paired Years

\begin{tabular}{lccc}
\hline \hline & $\begin{array}{c}\text { Between the years } \\
\text { before and after June 2004 } \\
\text { After June 2004 }\end{array}$ & $\begin{array}{c}\text { Between the years } \\
\text { before and after June 2005 } \\
\text { After July 2005 }\end{array}$ & $\begin{array}{c}\text { Between the years } \\
\text { before and after June 2006 } \\
\text { After July 2006 }\end{array}$ \\
\hline Difference-in-Differences & -0.045 & $-0.117 *$ & 0.022 \\
Standard Error & $(0.048)$ & $(0.055)$ & $(0.052)$ \\
Observations & 2128 & 2669 & 2572 \\
\hline Notes: Target Group: 16 to 25 Year Old Muslim Men; Comparison Group: 16 to 25 Year Old Non-Muslim Immigrant men. All \\
estimates are from OLS regressions. Robust Standard Errors clustered by groups and years are shown in parentheses. Robust \\
Standard Errors clustered by persons are shown in parentheses. Coefficients are shown with statistical significances where “**” \\
denotes significance at the 1\% level, “*” denotes significance at the 5\% level, and “+” denotes significance at the 10\% level. \\
\hline
\end{tabular}




\section{Appendix I: Summary Statistics for 16 to 29 Year Old Men from Muslim-majority}

Countries and the Comparison-Group Men

\begin{tabular}{|c|c|c|c|c|c|}
\hline Variables & Muslims & Other Immigrants & Difference & UK-Born & Difference \\
\hline Employment & 67.5 & 80.5 & $-13 * *$ & 84.6 & $-17.1 * *$ \\
\hline Observations & 3044 & 9264 & & 123143 & \\
\hline Hours Worked & 23.5 & 32.2 & $-8.7 * *$ & 33.5 & $-10 * *$ \\
\hline Observations & 2864 & 8605 & & 112672 & \\
\hline Weekly Earnings (Dollars) & 251 & 412 & $-161 * *$ & 345 & $-94 * *$ \\
\hline Observations & 437 & 1781 & & 25605 & \\
\hline Age & 25 & 25.1 & -0.1 & 23.6 & $1.4^{* *}$ \\
\hline UK Citizen (\%) & 48.5 & 28.5 & $20 * *$ & 100 & $-51.5^{* *}$ \\
\hline Married (\%) & 47 & 21 & $26 * *$ & 11.7 & $35.3^{* *}$ \\
\hline Length of stay in UK (Years) & 20.8 & 23.8 & $-3 * *$ & 23.6 & $-2.8 * *$ \\
\hline \multicolumn{6}{|l|}{ Educational Qualification (\%) } \\
\hline No Qualification & 25 & 7 & $18 * *$ & 8.7 & $16.3 * *$ \\
\hline Foreign Education & 25 & 35 & $-10 * *$ & 2.6 & $22.4 * *$ \\
\hline O-Level or Below & 15 & 10 & $5^{* *}$ & 33.3 & $-17.7 * *$ \\
\hline Missing Value & 9 & 10 & $-1+$ & 8.5 & 0.5 \\
\hline A level or Diploma Equivalent & 13 & 17 & $-4 * *$ & 29.5 & $-16.5^{* *}$ \\
\hline Bachelor's or Higher & 13 & 20 & $-7 * *$ & 17.4 & $-4.4 * *$ \\
\hline \multicolumn{6}{|l|}{ Industry (\%) } \\
\hline Agriculture \& Fishing & .47 & 0.75 & 0 & 1.24 & -0.77 \\
\hline Energy \& Water & 0.94 & 0.46 & 0 & 1.06 & -0.12 \\
\hline Manufacturing & 25.71 & 13.42 & $12.3 * *$ & 19.76 & $5.95^{* *}$ \\
\hline Construction & 1.89 & 5.16 & $-3 * *$ & 9.96 & $-8.07 * *$ \\
\hline Distribution, Hotels \& Restaurants & 34.91 & 24.37 & $10.5^{* *}$ & 22.43 & $12.48^{* *}$ \\
\hline Transport \& Communication & 10.38 & 7.17 & $3^{*}$ & 8.12 & $2.26+$ \\
\hline Banking, Finance \& Insurance & 13.44 & 25.97 & $-12.5 * *$ & 20.49 & $-7.05 * *$ \\
\hline Public Admin, Education \& Health & 8.96 & 15.60 & $-6.6^{* *}$ & 11.87 & $-2.91+$ \\
\hline Other Services & 3.30 & 7.05 & $-3.7 * *$ & 5.06 & $-1.76+$ \\
\hline Workplace Outside UK & 0.00 & 0.06 & 0 & 0 & 0 \\
\hline \multicolumn{6}{|l|}{ Occupation (\%) } \\
\hline Managers and Senior Officials & 4.95 & 11.46 & $-6.51 * *$ & 10.63 & $-5.68 * *$ \\
\hline Professional & 7.55 & 17.25 & $-9.70 * *$ & 11.48 & $-3.93 *$ \\
\hline Associate Professional and Technical & 8.49 & 19.77 & -11.28 & 14.89 & $-6.4^{* *}$ \\
\hline Administrative and Secretarial & 8.49 & 7.97 & -0.52 & 10.42 & -1.93 \\
\hline Skilled Trades & 11.79 & 8.94 & $2.85+$ & 18.68 & $-6.89 * *$ \\
\hline Personal Service & 4.48 & 5.96 & -1.48 & 3.98 & 0.5 \\
\hline Sales and Customer Service & 10.61 & 6.3 & $4.30 * *$ & 7.96 & $2.65+$ \\
\hline Process, Plant and Machine Operatives & 17.22 & 6.13 & $11.85^{* *}$ & 9.35 & $7.87 * *$ \\
\hline Elementary/Other & 26.42 & 16.22 & $10.20 * *$ & 12.6 & $13.82 * *$ \\
\hline
\end{tabular}




\section{Appendix I cont.: Summary Statistics for 16 to 54 Year Old Men from Muslim-} majority Countries and Comparison-Group Men

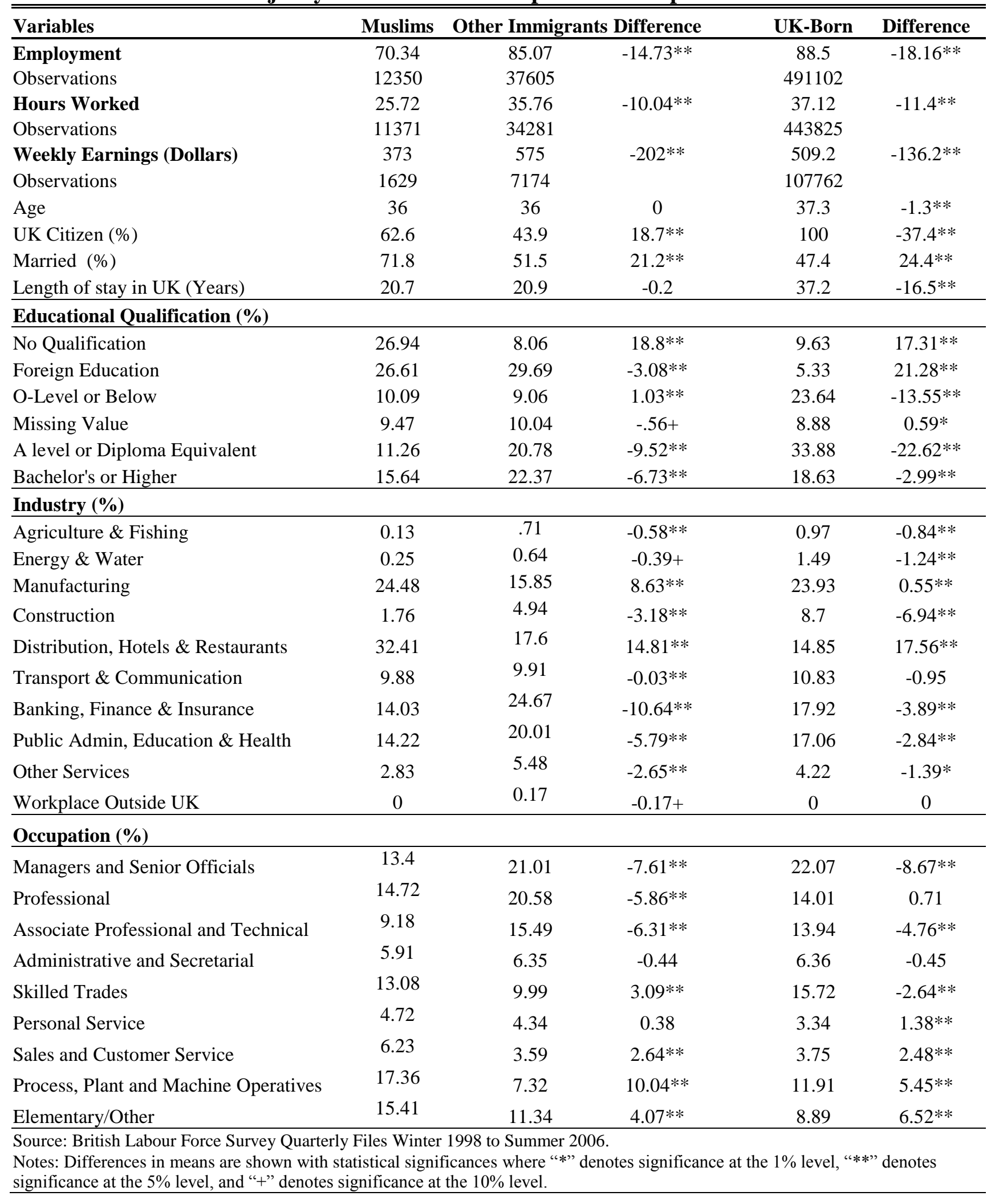




\section{Appendix II: Summary Statistics for 16 to 25 Year Old Muslim Men and Comparison-Group Men}

\begin{tabular}{|c|c|c|c|c|c|}
\hline Variables & Muslims & $\begin{array}{l}\text { Non-Muslim } \\
\text { Immigrants } \\
\end{array}$ & Difference & $\begin{array}{c}\text { Non- } \\
\text { Muslim } \\
\text { UK-Born } \\
\end{array}$ & Difference \\
\hline Employment (\%) & 60.3 & 75.8 & $-15.5^{* *}$ & 80.4 & $-20.1 * *$ \\
\hline Observations & 2004 & 2826 & & 46011 & \\
\hline Hours Worked & 20.6 & 29.1 & $-8.5 * *$ & 30.3 & $-9.7 * *$ \\
\hline Observations & 1872 & 2655 & & 42220 & \\
\hline Weekly Earnings (Pounds) & 246.4 & 328.3 & $-81.95 * *$ & 287.2 & $-40.8 * *$ \\
\hline Observations & 249 & 470 & & 8476 & \\
\hline Age & 22 & 22.5 & $-0.5 * *$ & 21.3 & $0.7 * *$ \\
\hline UK Citizen (\%) & 73.5 & 28.9 & $44.6^{* *}$ & 100 & $-26.5^{* *}$ \\
\hline Married (\%) & 18.4 & 9.2 & $9.2 * *$ & 3.7 & $14.7 * *$ \\
\hline Length of stay in UK (Years) & 16.3 & 7.2 & $9.1 * *$ & 21.3 & $-5 * *$ \\
\hline \multicolumn{6}{|l|}{ Educational Qualification (\%) } \\
\hline No Qualification & 16.67 & 9.31 & $7.3 * *$ & 9.45 & $7.2 * *$ \\
\hline Foreign Education & 10.68 & 32.17 & $-21.5 * *$ & 2.12 & $8.5 * *$ \\
\hline O-Level or Below & 27.30 & 13.02 & $14.3 * *$ & 36.3 & $-9 * *$ \\
\hline Missing Value (Put after Bachelor's) & 17.61 & 15.68 & $1.9+$ & 13.37 & $4.2 * *$ \\
\hline A level or Diploma Equivalent & 14.27 & 17.52 & $-3.2 * *$ & 27.44 & $-13.2 * *$ \\
\hline Bachelor's or Higher & 13.47 & 12.31 & 1.15 & 11.33 & $2.1^{* *}$ \\
\hline \multicolumn{6}{|l|}{ Industry (\%) } \\
\hline Agriculture \& Fishing & 0 & 1.28 & $-1.28+$ & 1.24 & $-1.24+$ \\
\hline Energy \& Water & 2.01 & 0.64 & $1.37+$ & 0.98 & 1.03 \\
\hline Manufacturing & 22.89 & 12.37 & $10.52 * *$ & 17.26 & $5.63^{*}$ \\
\hline Construction & 2.81 & 5.97 & $-3.16+$ & 12.64 & $-9.83 * *$ \\
\hline Distribution, Hotels \& Restaurants & 36.55 & 32.84 & 3.71 & 26.82 & $9.73 * *$ \\
\hline Transport \& Communication & 8.03 & 4.9 & $3.13+$ & 6.93 & 1.1 \\
\hline Banking, Finance \& Insurance & 20.48 & 20.47 & 0.01 & 17.53 & 2.95 \\
\hline Public Admin, Education \& Health & 6.02 & 14.29 & $-8.27 * *$ & 10.76 & $-4.74 *$ \\
\hline Other Services & 1.2 & 7.25 & $-6.05 * *$ & 5.84 & $-4.64 * *$ \\
\hline Workplace Outside UK & 0 & 0 & & 0 & 0 \\
\hline \multicolumn{6}{|l|}{ Occupation $(\%)$} \\
\hline Managers and Senior Officials & 3.61 & 5.33 & -1.72 & 6.72 & -3.11 \\
\hline Professional & 5.62 & 11.09 & $-5.47 *$ & 8.26 & $-2.64+$ \\
\hline Associate Professional and Technical & 9.24 & 18.12 & $-8.88 * *$ & 13.6 & -4.36 \\
\hline Administrative and Secretarial & 9.24 & 6.4 & 2.84 & 9.94 & $-0.7 *$ \\
\hline Skilled Trades & 9.64 & 12.15 & -2.51 & 21.35 & -11.71 \\
\hline Personal Service & 1.2 & 4.48 & $-3.28 *$ & 2.5 & $-1.3 * *$ \\
\hline Sales and Customer Service & 20.08 & 10.66 & $9.42 * *$ & 10.46 & 9.62 \\
\hline Process, Plant and Machine Operatives & 12.05 & 7.46 & $4.59 *$ & 8.64 & $3.41 * *$ \\
\hline Elementary/Other & 29.32 & 24.31 & 5.01 & 18.54 & $10.78+$ \\
\hline
\end{tabular}


Appendix III: Effects of July Bombings on Labor Market Outcomes of Men from Muslim-Majority Countries

\begin{tabular}{|c|c|c|c|c|c|c|}
\hline \multirow[b]{2}{*}{ Relative to Other Immigrants } & \multicolumn{2}{|c|}{$16-25$} & \multicolumn{2}{|c|}{$16-29$} & \multicolumn{2}{|c|}{$16-54$} \\
\hline & Basic & Full & Basic & Full & Basic & Full \\
\hline Employed $=1$ & $\begin{array}{l}-0.067 \\
(0.06)\end{array}$ & $\begin{array}{l}-0.03 \\
(0.07)\end{array}$ & $\begin{array}{l}-0.002 \\
(0.04)\end{array}$ & $\begin{array}{l}0.037 \\
(0.04)\end{array}$ & $\begin{array}{l}-0.006 \\
(0.02)\end{array}$ & $\begin{array}{l}-0.007 \\
(0.02)\end{array}$ \\
\hline Observations & 3125 & 3125 & 6709 & 6709 & 26812 & 26812 \\
\hline Weekly Hours Worked & $\begin{array}{l}-2.876 \\
(2.52)\end{array}$ & $\begin{array}{c}-1.038 \\
(2.76)\end{array}$ & $\begin{array}{l}-0.409 \\
(1.68)\end{array}$ & $\begin{array}{l}1.089 \\
(1.99)\end{array}$ & $\begin{array}{c}-0.553 \\
(0.90)\end{array}$ & $\begin{array}{l}-0.478 \\
(1.05)\end{array}$ \\
\hline Observations & 2939 & 2939 & 6237 & 6237 & 24514 & 24514 \\
\hline Log Weekly Earnings & $\begin{array}{l}-0.138 \\
(0.16)\end{array}$ & $\begin{array}{l}-0.176 \\
(0.22)\end{array}$ & $\begin{array}{l}0.027 \\
(0.11)\end{array}$ & $\begin{array}{l}-0.04 \\
(0.14)\end{array}$ & $\begin{array}{l}0.001 \\
(0.08)\end{array}$ & $\begin{array}{l}0.037 \\
(0.09)\end{array}$ \\
\hline Observations & 510 & 510 & 1213 & 1213 & 4718 & 4718 \\
\hline \multicolumn{7}{|l|}{ Relative to All UK-Born Men } \\
\hline Employed $=1$ & $\begin{array}{l}0.003 \\
(0.05)\end{array}$ & $\begin{array}{l}0.006 \\
(0.06)\end{array}$ & $\begin{array}{l}0.039 \\
(0.03)\end{array}$ & $\begin{array}{l}0.056 \\
(0.04)\end{array}$ & $\begin{array}{l}0.014 \\
(0.02)\end{array}$ & $\begin{array}{l}0.014 \\
(0.02)\end{array}$ \\
\hline Observations & 29026 & 29026 & 45164 & 45164 & 181562 & 181562 \\
\hline Weekly Hours Worked & $\begin{array}{l}0.993 \\
(2.20)\end{array}$ & $\begin{array}{l}0.072 \\
(2.33)\end{array}$ & $\begin{array}{l}2.284 \\
(1.49)\end{array}$ & $\begin{array}{c}2.34 \\
(1.75)\end{array}$ & $\begin{array}{c}0.64 \\
(0.82)\end{array}$ & $\begin{array}{l}0.818 \\
(0.95)\end{array}$ \\
\hline Observations & 26661 & 26661 & 41393 & 41393 & 164182 & 164182 \\
\hline Log Weekly Earnings & $\begin{array}{l}-0.009 \\
(0.14)\end{array}$ & $\begin{array}{l}0.038 \\
(0.20)\end{array}$ & $\begin{array}{l}0.079 \\
(0.10)\end{array}$ & $\begin{array}{c}0.07 \\
(0.12)\end{array}$ & $\begin{array}{l}-0.029 \\
(0.07)\end{array}$ & $\begin{array}{l}0.077 \\
(0.08)\end{array}$ \\
\hline Observations & 5130 & 5130 & 8661 & 8661 & 37771 & 37771 \\
\hline $\begin{array}{l}\text { Notes: All regressions include da } \\
\text { interaction between Muslim dum } \\
\text { except log weekly earning, hours } \\
\text { include only employed men. In t } \\
\text { "persons" are shown in parenthe } \\
1 \% \text { level, "*" denotes significan }\end{array}$ & $\begin{array}{l}\text { ro worke } \\
\text { oefficien } \\
\text { e } 5 \% \text { le }\end{array}$ & 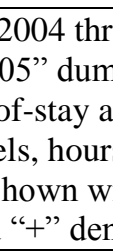 & $\begin{array}{l}\text { equal to } \\
\text { tical sign } \\
\text { nificance }\end{array}$ & $\begin{array}{l}\text { Entries a } \\
\text { e given } \\
\text { te are ca } \\
\text { t emplo } \\
\text { where “ } \\
\% \text { level. }\end{array}$ & $\begin{array}{l}\text { lated coef } \\
\text { regressio } \\
\text { l. Log ear } \\
\text { ndard err } \\
\text { otes signi }\end{array}$ & $\begin{array}{l}\text { S of the } \\
1 \text { variable } \\
\text { models } \\
\text { stered by } \\
\text { e at the }\end{array}$ \\
\hline
\end{tabular}




\section{ENDNOTES}

${ }^{1}$ A comprehensive record of the impacts of the European terrorists events can be found in reports of the European Monitoring Center on Racism and Xenophobia (EUMC) (May 2002, November 2005).

${ }^{2}$ In the Netherlands and Denmark, many Islamic websites were inundated with hate speech and the amount of antiMuslim text messages increased dramatically after 9/11. A number of opinion polls confirmed that the Danish majority believed that $9 / 11$ had made them become more negative towards Muslims, where the vast majority of the population felt that Muslims should be made to take lessons in Danish democratic values. Denmark had national elections coinciding with the aftermath of $9 / 11$ and animosity towards Muslims seemed to be visible in the political sphere too. Changes in attitude towards Muslims and a resulting trend of hostility were identified in the Danish workplaces too. Series of opinion polls in the Netherlands indicate that a large part the population was in favor of the deportation of Muslims whilst others were keen to see asylum seekers from Muslim backgrounds being refused entry to the country. Another poll declared the Dutch population's belief that Islam presented them with a very real threat. The killing of the author of a documentary about Muslim immigrants by a Dutch-Moroccan (November 2004) Muslim added to the perceived danger.

${ }^{3}$ Kaestner et al. (2007) regress "earnings" for employed individuals. For their "hours-worked" regressions, they include all individuals setting hours equal to zero for men who were not employed. We do the same in the OLS regressions but for the quantile earning regressions, we include all men assigning log of earnings equal to zero if not employed. This is done to avoid the sample selection bias occurring in the mean regression.

${ }^{4}$ The recession that began in March 2001 is potentially one such confounding factor. Estimation of the pre- and post-9/11 changes in outcome using only the target-group (i.e. Mislims) sample may generate a negative coefficient simply because of the business-cycle downturn.

${ }^{5}$ To control for industry of work, 9 major industry dummy variables were used. To control for occupations we constructed ten major occupation groups. However, we use "percentage of group members working in the respective occupation" to control for occupational variations instead of using occupation dummies. Exclusion of this variable does not significantly affect the difference in differences effect.

${ }^{6}$ We follow the specifications of Kaestner et al. (2004) here. We find coefficients of the time-trend variables always negligible and statistically insignificant. Models with month dummy variables yielded similar results.

${ }^{7}$ In the case of probit, the interaction effect is estimated by taking the average of difference-in-differences of the predicted probabilities.

${ }^{8}$ Kaestner et al. allowed the effect of September $11^{\text {th }}$ to differ according to an index of hate crime/discrimination against Arabs and Muslims. They used three measures of September 11th related hate crime or discrimination: number of hate crime/discrimination incidents reported in a state; number of hate crime/discrimination incidents per Arab population in a state; and number of hate crime/discrimination incidents per state population. While the first two capture the risk of discrimination Arabs and Muslims face in a state, the third is an indicator of the prevalence of prejudice among the non-Arab population. Prior to October 2001, value of hate-crime index was assumed to be zero in all states ${ }^{8}$. They estimated the results using all three indices and found the effects of all of them to be statistically insignificant. Due to the insignificant effects and the limited nature of the data, we do not include the indices in the analyses.

${ }^{9}$ Unlike in the US sample, we drop men between age 55 and 64 from the UK sample for two reasons. First, unlike in the US, about 90 percent of the target group members are below 55 in the UK. Second, about half of the "Muslims" over the age 54 in the UK are out of labor force in contrast to less than one-third of the comparisongroup members. Questionnaires in the US and the UK surveys are similar and the data collection methods are comparable making it possible to use the same method to analyze both data sets.

${ }^{10}$ There has been no study on whether the $1^{\text {st }}$ generation immigrants were affected more than the $2^{\text {nd }}$-generation immigrants. Anti-terrorism laws and programs targeted primarily those $1^{\text {st }}$ generation immigrants who are not US citizens, especially those who are not residing or working legally in the US. A fraction of the $1^{\text {st }}$ generation immigrants in the CPS datasets should be illegal immigrants. Demographic research suggests that at least a fraction of the illegal immigrants are in the CPS since the number of immigrants enumerated by the survey (and by the 
decennial Census, upon which the CPS weights are based) exceeds estimates of the number of the foreign-born legally present in the U.S.

${ }^{11}$ Until Spring 2002, the UK data does not identify men who are Muslim by religious affiliation (i.e., target group B). Therefore, a small fraction of comparison group 2 would include UK-born Muslims.

${ }^{12}$ Consistent with the literature, we find that marriage, years in the UK, and UK citizenship is associated with higher earnings and employment.

${ }^{13}$ The outcomes before and after 9/11 for "Muslims" age 16-54 in the UK are available upon request.

${ }^{14}$ The lower educational attainment of Muslims (compared to other immigrants) explains the largest portion of the employment gap. However, over $90 \%$ of the total gap remains unexplained.

${ }^{15}$ Results available from the authors on request.

16 "Rise in Muslim Discrimination", BBC news, 16 December 2004.

http://news.bbc.co.uk/2/hi/uk_news/4102389.stm

${ }^{17}$ Results available from the authors on request.

${ }^{18} \mathrm{We}$ also explored estimating median regressions that include the unemployed as having zero earnings. This was not feasible because more than fifty percent of the sample reported zero earnings.

${ }^{19}$ EUMAP - EU Monitoring and Advocacy Program - Aspirations and Reality: British Muslims and the Labour Market. 